\title{
Development of Motion Graphic as Education Material for Promoting Shipping Industry Using EPIC Model Testing
}

\author{
Mirza Oktanizar $^{1}$, Dwi Ely Kurniawan ${ }^{2}$ \\ ${ }^{1}$ Department of Multimedia Engineering, Politeknik Negeri Batam, Batam, Indonesia \\ ${ }^{1}$ mirzaoktanizar@gmail.com \\ ${ }^{2}$ Department of Informatics Engineering, Politeknik Negeri Batam, Batam, Indonesia \\ 2dwialikhs@polibatam.ac.id
}

Accepted on October 22, 2020

Approved on June 18, 2021

\begin{abstract}
Education related to problems in the shipping industry to the general public who have no background in the shipping industry and activities when ships dock at the port becomes a challenge to conduct research. This research develops multimedia motion graphics to combine graphic design, animation, text, and sound in visualizing materials and activities in the shipping industry. Stages of making multimedia start from ideas, narration, storyboard, tracing, editing, rendering, and testing. The research uses the EPIC Model testing by paying attention to aspects of empathy, persuasion, impact, and communication. The results of testing the effectiveness of the EPIC model obtained an EPIC rate of 4.15, which means that the resulting motion graph falls within the effective range criteria.
\end{abstract}

Index Terms-effectiveness; EPIC model; motion graphic; multimedia

\section{INTRODUCTION}

Maritime shipping is a prime example of an increasingly globalized industry [1]. Maersk Line is a transnational company that has become the world's leading container carrier. Mr. Ib Kruse, one of a person in change at Maersk Line, explained how the company's competitiveness rested on a service 'second to none, realized through the combination of modern and effective company-owned ships with sophisticated equipment developed in-house, a global network of own company offices and high-level communication, and sophisticated documentation and control systems [2]. Maersk Line is an example of a modern company in the shipping industry. There are still many shipping companies that still using the traditional system and wasting my time and cost to do one Port of Call. A promotion media needed to show and educate everyone that in this modern era we need to use technology to minimize costing and wasting time, especially in the shipping industry.

Education needed to tell other people how the shipping industry works. History learning became problematic currently, because of the lack of utilization, imagination, and state-oriented textbooks and curriculum [14]. Nowadays, technology is an important thing to have. Government, researchers, the education system, or researchers now considering technology an important thing for education [13]. To improve education quality, learning media is used to optimize the learning process and teaching strived to be able to grow motivation and creativity [15-17]. The education/learning media is using a promotional video.

Promotion is an marketing mixed element that focused on giving information, persuading, and reminding customers about the company brand and product [3]. In this modern era, promotion can be done so easily. We do not need to meet in person because we can just spread it via the internet. Promotional media plays important role in determining rating access in search engines by using SEO, SEM, and SMO technic [4][5]. Everyone who is connected to the internet can easily find every promotion on the internet. By creating this promotional media, hoping that can give education to people out there about the shipping industry.

In this research, promotional media that will be used is a video in the form of motion graphics. Video media has one of the advantages that video can overcome the limitations of time and space, is more realistic, and can be repeated [6]. Motion graphics are a combination of illustrations, photos, or other forms of digital art that are visualized into a video and accompanied by musical instruments [7]. After creating the video we also needed to know about its effectiveness for conveying to people about the shipping industry.

Based on the background above, the objective of this research is to create promotional media in a form of motion graphics and will be analyzed for the level of effectiveness using the EPIC Model to find out whether the promotional video is effective or not. 


\section{METHOD}

The research method that is used in this research is using EPIC Model to find the level of effectiveness from the motion graphic that was created. EPIC model is a measure of advertising effectiveness developed by AC Nielsen, a leading market research company using a communication approach [9]. There are 4 critical dimensions in EPIC Model, there are empathy, persuasion, impact, and communication [10]. Roscoe in the book research methods for business (1982: 253) suggests a decent sample size in a study with a distance between 30 to 500 respondents [11].

The measuring instrument will be used in the form of a questionnaire distributed via Google Form. Target respondents addressed to 30 respondents including 10 people aged 17-25 years, 10 people aged 25-35 years, 10 people aged 35-60 years

The analysis phase is divided into 2 parts, alpha testing, and beta testing. The alpha testing will be tested for validity and reliability. The data obtained can be said to be valid if obtained from measuring instruments that are valid [11] [16]. Furthermore, in beta testing, EPIC Model analysis will be performed. A chart of the research stages is shown in Fig. 1 Research stages.

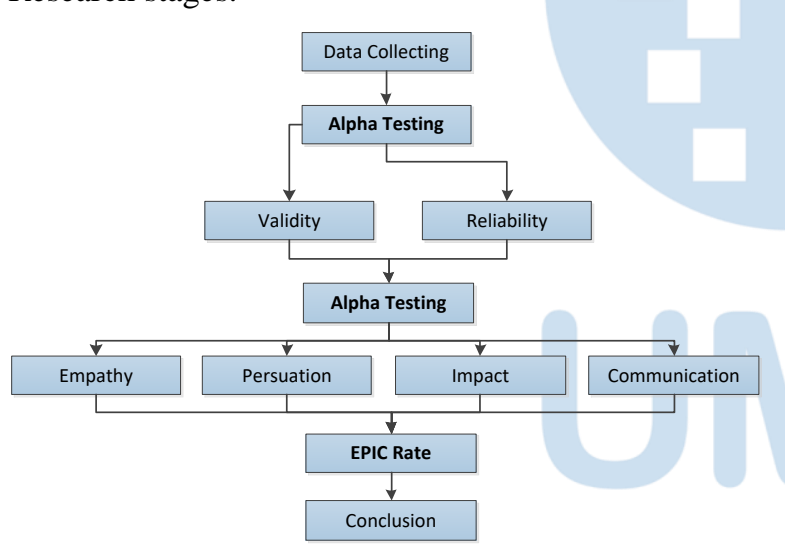

Fig. 1. Research stages

Before we reaching to the analysis, a draft for producing the motion graphic is needed. You can find below the full draft of creating the motion graphic from brainstorming about the idea to the final product, which is a motion graphic video in MP4 format.

\section{A. Idea Development}

The process that is carried out at this stage is to develop ideas and concepts that exist in making motion graphics that will be implemented as promotional media. The idea of making promotional media that applies motion graphics was initially carried out with interviews. The results of interviews in the form of ideas in making motion graphics on activities when the ship is anchored at the port, problems commonly experienced in the shipping industry.

The duration of this motion graphic will be made in 1-2 minutes so that the video will run faster with the amount of information provided, this motion graphic will combine several elements such as graphic design, text, narration, and music.

\section{B. Narration}

Narration will help convey the message in the video. The narration in the motion graphic will be in the form of sound that accompanies the motion graphic running and in the form of text that is located in several scenes in the motion graphic. The voice narration will be adjusted back to the visual video when the motion graphic has entered the scene merging stage in Adobe Premiere Pro CS6.

\section{TABLE I. NARRATION}

\begin{tabular}{|c|c|c|}
\hline Scene & Voice narration & Visual narration \\
\hline 2 & $\begin{array}{l}\text { Many activities take } \\
\text { place when a ship } \\
\text { enters the port, such } \\
\text { as crew changes cargo } \\
\text { operations } \\
\text { inspections and } \\
\text { surveys repair and } \\
\text { maintenance supplies } \\
\text { and victualing } \\
\text { bunkering, and many } \\
\text { more. }\end{array}$ & $\begin{array}{l}\text { A ship's port } \\
\text { call consists of } \\
\text { many activities } \\
\text { such as } \\
\text { modifications, } \\
\text { victualing, water } \\
\text { supply, pilotage, } \\
\text { towage, spares } \\
\text { supply, shore } \\
\text { leave, crew } \\
\text { training, cash to } \\
\text { master, dry } \\
\text { docking, hull } \\
\text { cleaning, } \\
\text { surveyors, } \\
\text { bunkering, } \\
\text { supplies, repair, } \\
\text { inspection, cargo } \\
\text { operations, crew } \\
\text { change. }\end{array}$ \\
\hline 3 & $\begin{array}{l}\text { Meanwhile in the ship } \\
\text { management onshore. }\end{array}$ & $\begin{array}{l}\text { Meanwhile in the } \\
\text { ship management } \\
\text { onshore. }\end{array}$ \\
\hline 4 & $\begin{array}{l}\text { We are using too many } \\
\text { modes of } \\
\text { communications } \\
\text { Email is overloaded } \\
\text { And coordinating with } \\
\text { so many stakeholders } \\
\text { is complicated } \\
\text { No data is collected } \\
\text { from each port call } \\
\text { for optimization } \\
\text { And no live overview } \\
\text { of ship activities is } \\
\text { available onshore } \\
\text { And the single point } \\
\text { coordinator of the } \\
\text { entire port call is a } \\
\text { point source of } \\
\text { failure. }\end{array}$ & $\begin{array}{l}\text { Too many modes of } \\
\text { communication } \\
\text { Email overload is } \\
\text { real! } \\
\text { It's complicated } \\
\text { coordinating with } \\
\text { so many people! } \\
\text { And at the end of } \\
\text { the day, no data } \\
\text { is collected for } \\
\text { analysis } \\
\text { No live overview } \\
\text { of ship } \\
\text { activities } \\
\text { Point Source of } \\
\text { Failure }\end{array}$ \\
\hline
\end{tabular}




\begin{tabular}{|c|c|c|}
\hline 5 & $\begin{array}{l}\text { But Now, There is a } \\
\text { better way } \\
\text { Introducing constant } \\
\text { bearing port call } \\
\text { planning tool }\end{array}$ & $\begin{array}{l}\text { But now, there is } \\
\text { a battery way } \\
\text { Introducing } \\
<\text { logo> port call } \\
\text { planning tool }\end{array}$ \\
\hline 6 & $\begin{array}{l}\text { A simple } 5 \text { step } \\
\text { workflow that } \\
\text { captures key } \\
\text { information, such as } \\
\text { activities for this } \\
\text { port call and } \\
\text { stakeholder involved } \\
\text { a schedule is } \\
\text { generated that can be } \\
\text { edited and published } \\
\text { This allows for easy } \\
\text { collaboration between } \\
\text { stakeholders and data } \\
\text { collection for } \\
\text { further improvement } \\
\text { What's your next } \\
\text { milestone? } \\
\text { Make constant Bearing } \\
\text { your next port of } \\
\text { call in your } \\
\text { digitization voyage }\end{array}$ & $\begin{array}{l}\text { What's your next } \\
\text { milestone? } \\
\text { Make us your next } \\
\text { port of call in } \\
\text { your digitization } \\
\text { voyage. }\end{array}$ \\
\hline
\end{tabular}

\section{Storyboard}

At this stage, a storyboard is created to sketch out a depiction of a story from a motion graphic that will be implemented as promotional media.

TABLE II. STORYBOARD

\begin{tabular}{|l|l|l|}
\hline $\begin{array}{c}\text { Scene : } \\
\text { Sequence : }\end{array}$ & \multicolumn{1}{c|}{\begin{tabular}{c}
\multicolumn{1}{c|}{ Information } \\
\hline 2
\end{tabular}} & $\begin{array}{l}\text { Logo at the opening of video } \\
\text { Framing : Full Shot } \\
\text { BGM : upbeat music no } \\
\text { copyright } \\
\text { SFX : wave sound effects }\end{array}$ \\
\hline \begin{tabular}{l} 
Scene : \\
\hline 2
\end{tabular} & $\begin{array}{l}\text { Sequence : } \\
\text { move forward beside a } \\
\text { moving text }\end{array}$ \\
\hline
\end{tabular}

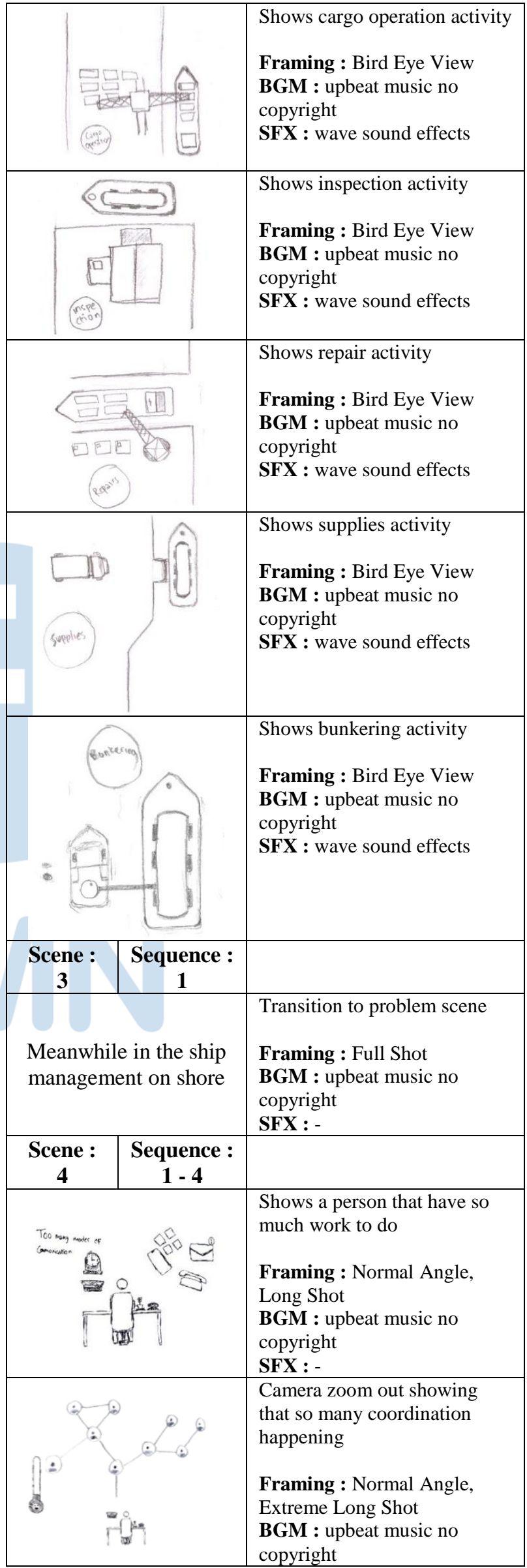

copyright 


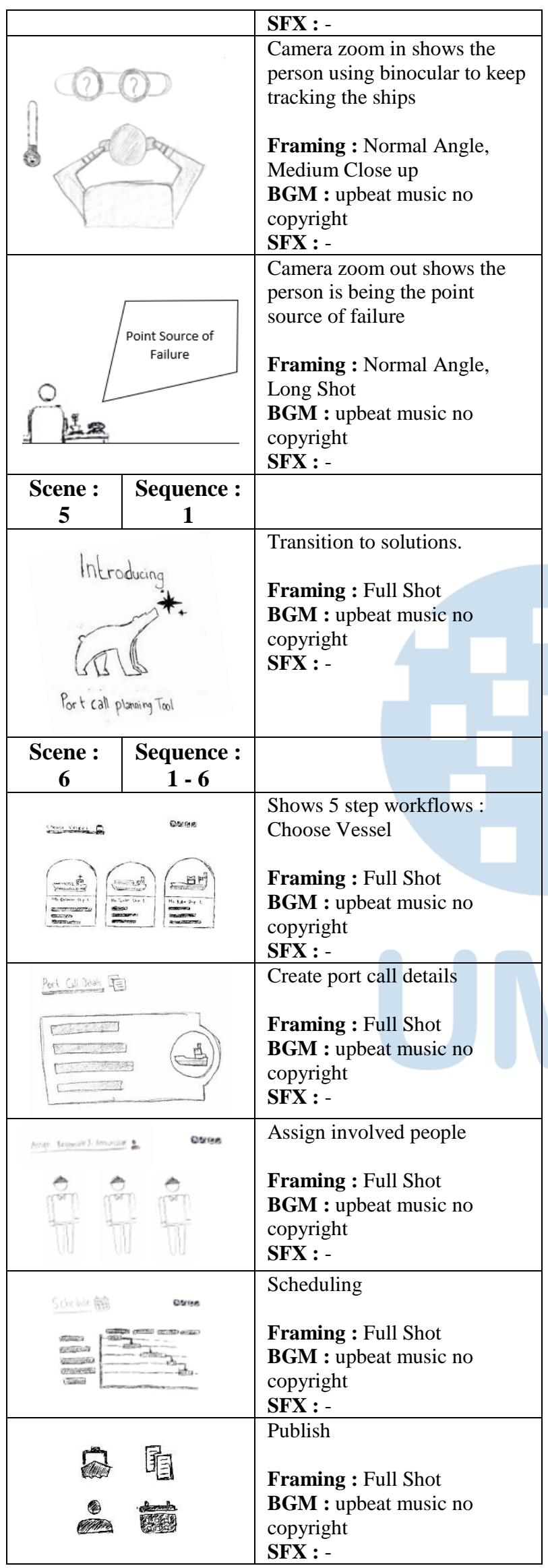

\begin{tabular}{|l|l|}
\hline $\begin{array}{l}\text { Scene : } \\
\text { Sequence : }\end{array}$ & $\begin{array}{l}\text { See every stakeholder involve } \\
\text { is collaborating } \\
\text { BGM : upbeat music no } \\
\text { copyright } \\
\text { SFX : - }\end{array}$ \\
\hline & $\begin{array}{l}\text { Showing logo at the end of the } \\
\text { video }\end{array}$ \\
& $\begin{array}{l}\text { Framing : Full Shot } \\
\text { BGM : upbeat music no } \\
\text { copyright } \\
\text { SFX : - }\end{array}$ \\
\hline
\end{tabular}

\section{Tracing and Coloring}

The process carried out at this stage is to create objects from sketches that have been made into digital form using the Adobe Illustrator CS6 application.

TABLE III. TRACING AND COLORING PROCESS

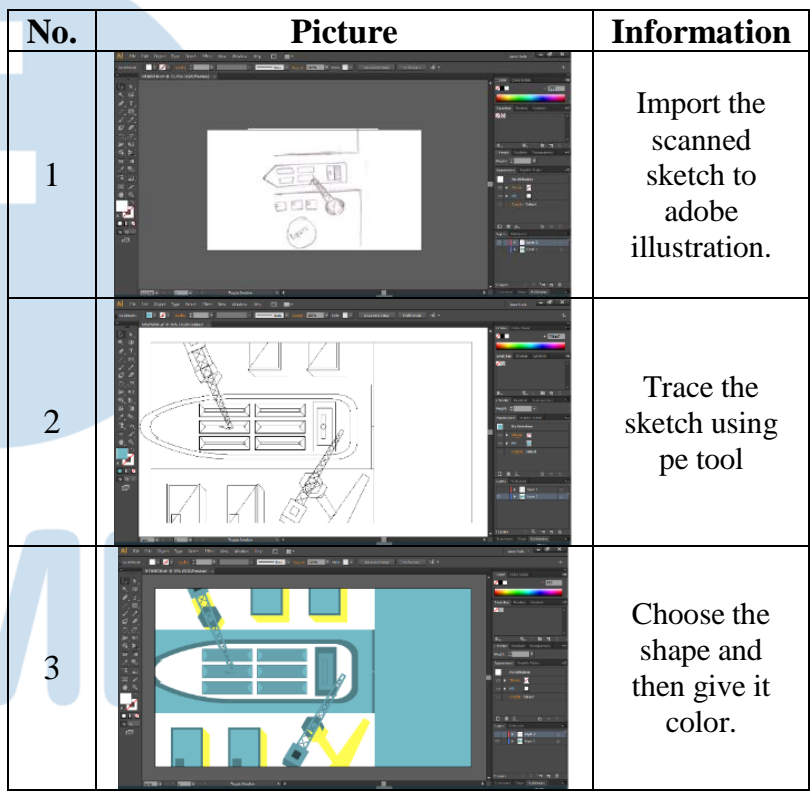

TABLE IV. TRACING AND COLORING RESULtS

\begin{tabular}{|l|c|c|}
\hline No. & Sketch & Tracing and Coloring \\
\hline 1 & & \\
\hline 2 & & \\
\hline
\end{tabular}




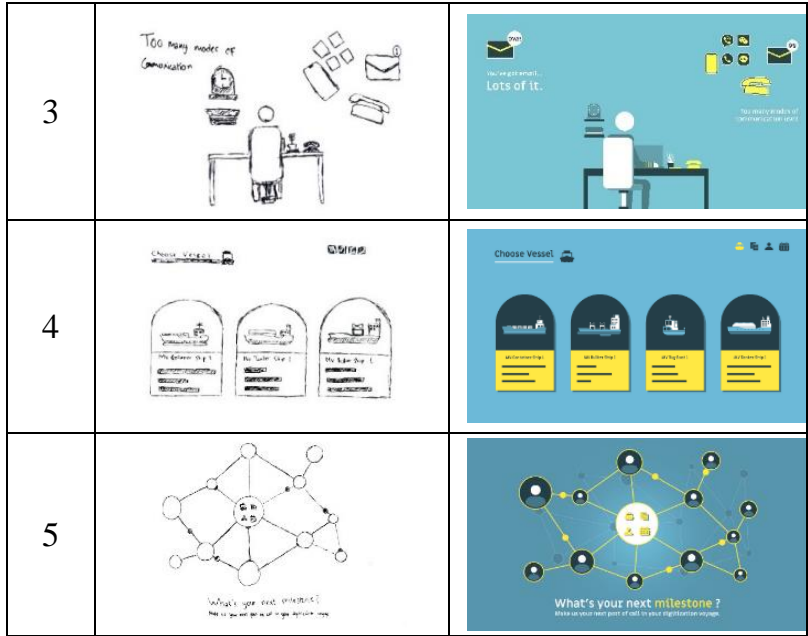

\section{E. Animating}

After going through the Tracing and Coloring stage, the next step is Animating. At this stage, the objects from the Tracing will be animated using the Adobe AfterEffects CS6 application. Visual effects that are given to objects that change the Scale, Rotation, Position, and Opacity. This study also used the 3D Movement Camera technique. 3D Movement Camera is one of the features in Adobe AfterEffect CS6. How to use the Camera in Adobe AfterEffect CS6 is to click on Layer then select New then select Camera, adjust the camera settings as needed. The animating stage is shown in Fig 2. Animating.

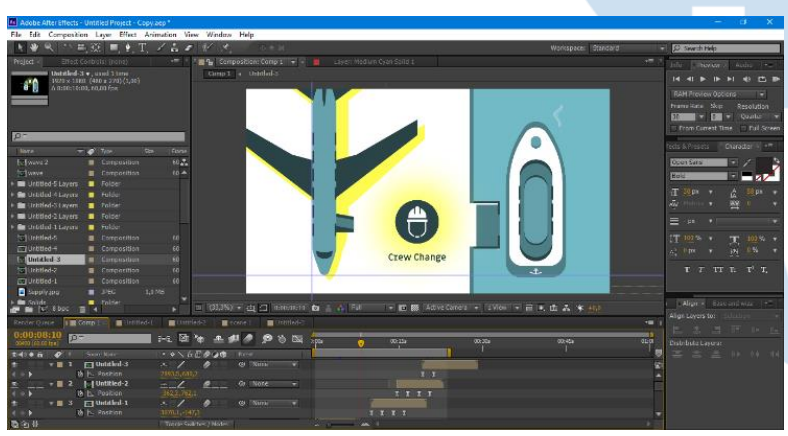

Fig. 2. Animating

\section{F. Editing}

After finishing animating, the next thing to do is editing. At this stage what is done is to combine Audio and Animation that has been made into a video. The software used at this stage is Adobe Premiere Pro CS6. The editing stage is shown in Fig. 3. Editing.

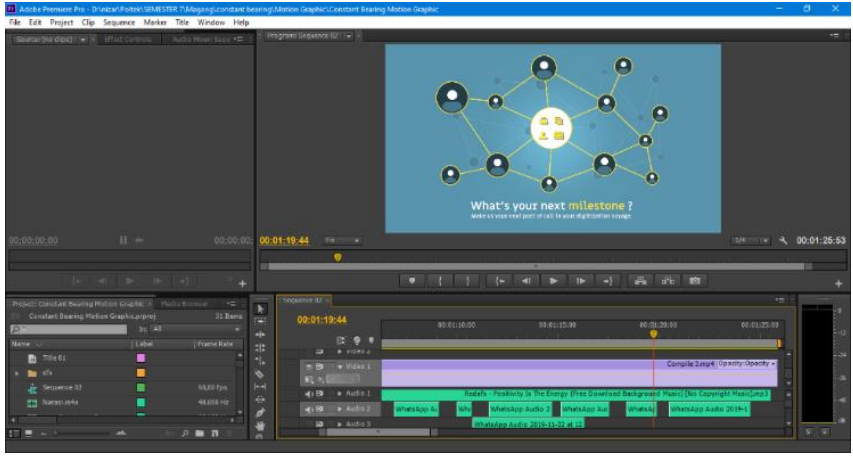

Fig. 3. Editing

\section{G. Rendering}

This stage is the last stage of the production process, namely rendering. Rendering is done after the Editing stage is finished, then Render will be done using the same software, namely Adobe Premiere Pro CS6. The Rendering stage is shown in Fig. 4. Rendering.

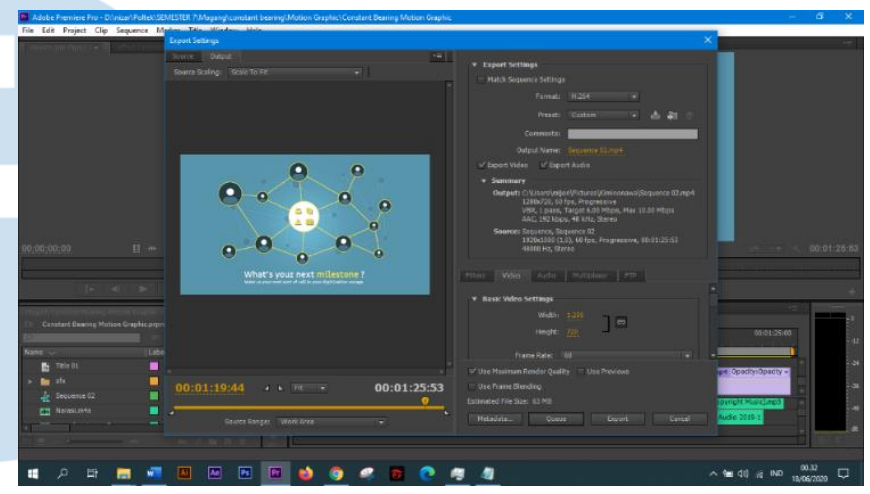

Fig. 4. Rendering

\section{H. Questionnaire}

Here is the questionnaire that used in this research.

TABLE V. QUESTIONNAIRE

\begin{tabular}{|l|l|}
\hline No. & Statement/Question \\
\hline \multicolumn{2}{|c|}{ Empathy } \\
\hline 1 & $\begin{array}{l}\text { Promotional video that are displayed are easy to } \\
\text { remember }\end{array}$ \\
\hline 2 & $\begin{array}{l}\text { Promotional videos that are displayed give an } \\
\text { impression to the company. }\end{array}$ \\
\hline 3 & I like the promotional videos that are displayed. \\
\hline \multicolumn{2}{|c|}{ Persuasion } \\
\hline 4 & $\begin{array}{l}\text { The solution offered in the promotional video gives } \\
\text { confidence to use the company's services. }\end{array}$ \\
\hline 5 & $\begin{array}{l}\text { The information provided in the promotional video } \\
\text { gives trust to the company. }\end{array}$ \\
\hline 6 & $\begin{array}{l}\text { Promotional videos provide an understanding of the } \\
\text { problems faced at port and solutions that must be } \\
\text { done. }\end{array}$ \\
\hline 7 & $\begin{array}{l}\text { Promotional video that are displayed give me interest } \\
\text { to use the service }\end{array}$ \\
\hline \multicolumn{2}{|c}{ Communication } \\
\hline
\end{tabular}




\begin{tabular}{|l|l|}
\hline 8 & $\begin{array}{l}\text { The information conveyed in the promotional video } \\
\text { is clear. }\end{array}$ \\
\hline 9 & $\begin{array}{l}\text { Promotional videos that are displayed give curiosity } \\
\text { about the company }\end{array}$ \\
\hline 10 & $\begin{array}{l}\text { The information in the promotional video is easy to } \\
\text { understand. }\end{array}$ \\
\hline
\end{tabular}

\section{RESUlT AND DISCUSSION}

\section{A. Alpha Testing}

In alpha testing will be tested for validity and reliability. The results of the measurement of the validity test that have been carried out are valid for all items contained in the questionnaire. Validity test results can be seen in Table VI. Validity Test.

TABLE VI. VALIDITY TEST

\begin{tabular}{|c|c|c|c|}
\hline No.Item & $\begin{array}{c}\text { Pearson } \\
\text { correlation }\end{array}$ & $\begin{array}{c}\text { Sig. } \\
(\boldsymbol{\alpha}=\mathbf{0 , 0 5})\end{array}$ & Results \\
\hline \multicolumn{4}{|c|}{ Empathy } \\
\hline 1 & 0,680 & 0,361 & Valid \\
2 & 0,612 & 0,361 & Valid \\
3 & 0,642 & 0,361 & Valid \\
\hline \multicolumn{4}{|c|}{ Persuasion } \\
\hline 4 & 0,407 & 0,361 & Valid \\
5 & 0,395 & 0,361 & Valid \\
\hline \multicolumn{4}{|c|}{ Impact } \\
\hline 6 & 0,616 & 0,361 & Valid \\
7 & 0,771 & 0,361 & Valid \\
\hline \multicolumn{5}{|c|}{ Communication } \\
\hline 8 & 0,621 & 0,361 & Valid \\
9 & 0,642 & 0,361 & Valid \\
10 & 0,654 & 0,361 & Valid \\
\hline
\end{tabular}

After obtaining the validity level of the statement item, the next step is to measure the level of consistency of the questionnaire by conducting a reliability test using the Cronbach's Alpha method. If Cronbach's alpha value is greater than 0,60 then the questionnaire used is declared reliable but if otherwise the questionnaire is considered unreliable [11]. After being calculated, the questionnaire used in this study proved to be reliable. The reliability test results can be seen in Table VII. Reliability Test.

TABLE VII. RELIABILITY TEST

\begin{tabular}{|c|c|c|}
\hline $\begin{array}{c}\text { Cronbach's } \\
\text { Alpha }\end{array}$ & N of Items & Results \\
\hline 0,808 & 10 & Reliable \\
\hline
\end{tabular}

\section{B. Beta Testing}

After getting that each statement is valid and the questionnaire used is reliable, the next step is to look for the value of the effectiveness of the EPIC Model and calculate the EPIC Rate. The effectiveness scale of the EPIC Model will be shown in Table VIII. EPIC Model Scale.
TABLE VIII. EPIC MODEL SCALE

\begin{tabular}{|l|c|}
\hline Category & Scale \\
\hline Strongly Agree & $1,00-1,80$ \\
\hline Agree & $1,81-2,60$ \\
\hline Neutral & $2,61-3,40$ \\
\hline Disagree & $3,41-4,20$ \\
\hline Strongly Disagree & $4,21-5,00$ \\
\hline
\end{tabular}

\section{Empathy}

Three statements represent the empathy dimension. The first statement gets a value of 4,13 , the second statement gets a value of 4,2 , the third statement gets a value of 4,37 . The three values obtained will then be calculated on average to determine the value of the empathy dimension. The value obtained for the empathy dimension is 4,19 , so for the empathy dimension, it is considered effective.

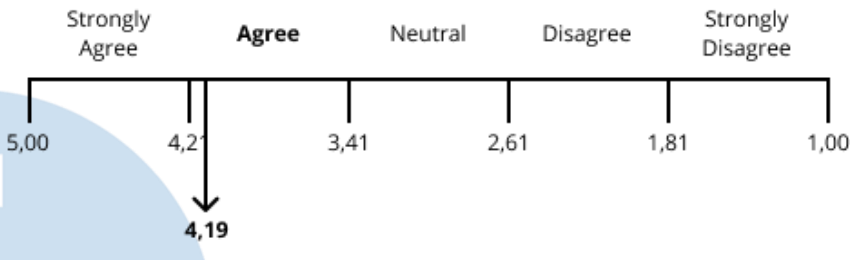

This indicates that promotional videos that are created can make consumers interested in promotional videos and can give an idea of how consumers see the relationship between themselves and the videos are shown.

\section{Persuasion}

Two statements represent the empathy dimension. The first statement gets a value of 4,3 and the second statement gets a value of 4,07. The two values obtained will then be calculated on average to determine the value of the dimension of persuasion. The value obtained for the dimension of persuasion is 4.19 , so the empathy dimension is considered effective.

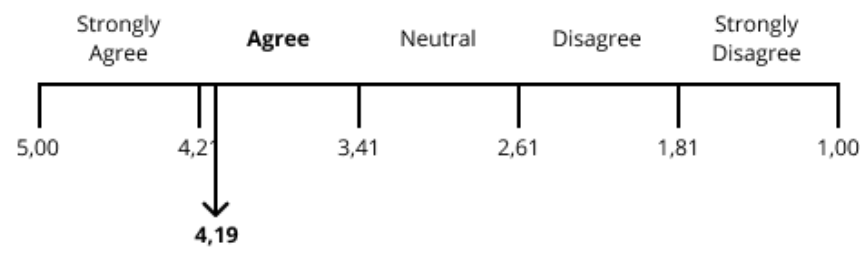

This indicates that promotional videos created can be used to persuade someone in a variety of different circumstances.

\section{Impact}

Two statements represent the impact dimension. The first statement gets a value of 4,17 and the second statement gets a value of 4,17 . The two values obtained will then be calculated on average to determine the value of the impact dimension. The 
value obtained for the impact dimension is 4,17 , so the empathy dimension is considered effective.

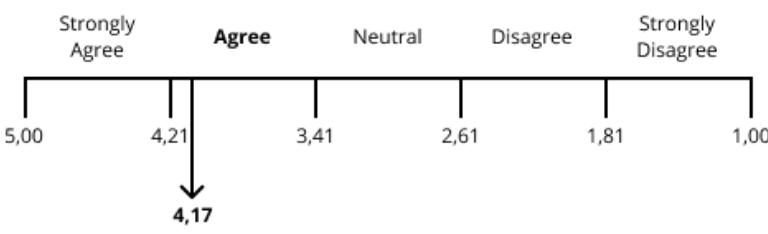

This indicates that the promotional video displayed provides new knowledge about the shipping industry.

\section{Communication}

Three statements represent the communication dimension. The first statement gets a value of 4,03, the second statement gets a value of 4,2 , the third statement gets a value of 3,93 . The three values obtained will then be calculated on average to determine the value of the empathy dimension. The value obtained for the empathy dimension is 4.06 , so the empathy dimension is considered effective.

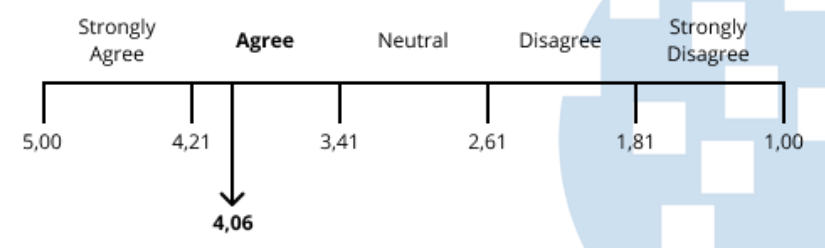

This indicates that the message conveyed and the information contained in the promotional video displayed is clear and easy to understand.

\section{EPIC Rate}

Next is to determine the EPIC Rate by calculating the average value of each dimension. The EPIC Rate obtained is 4,15 , thus the promotional video created is effectively used as promotional media.

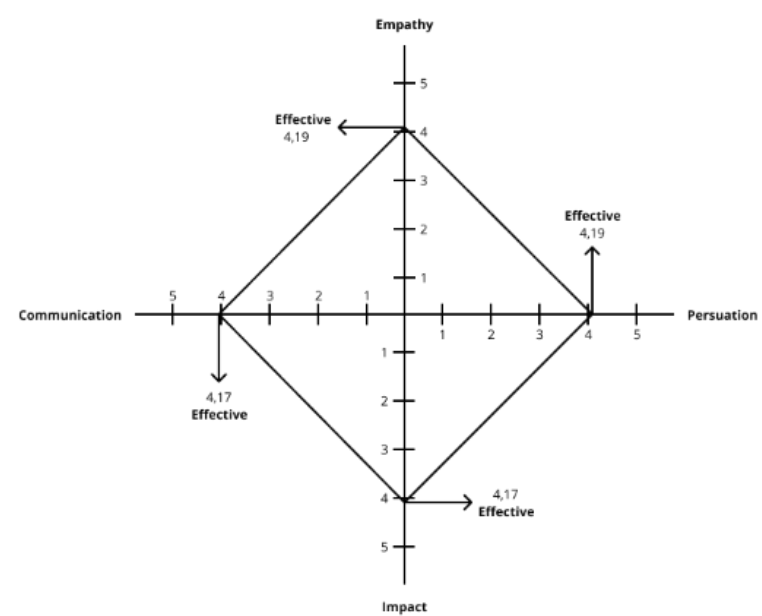

\section{CONCLUSION}

Based on the result and discussion above, we can have a conclusion that: (1) promotional media in a form of motion graphic has been successfully made, in MP4 format and have a duration of 1 minute 25 seconds; (2) The challenge faced at the production stage is having to load a lot of information into a video that has a short duration so that there are some sentences in the video that cannot be read because of the short video duration and the video tempo is fast, but sentences that are not legible can be helped by their existence voice over. (3) promotional videos that created can make consumers interested in promotional videos and can give an idea of how consumers see the relationship between themselves and the videos shown; (4) promotional video that created can be used to persuade someone in a variety of different circumstances; (5) promotional video displayed provide new knowledge about the shipping industry; and (6) the message conveyed and the information contained in the promotional video displayed is clear and easy to understand.

\section{REFERENCES}

[1] T. Lane and etc., The global seafarer: Living and working conditions in a globalized industry. Genève, Switzerland: International Labour Office, 2004.

[2] H. Sornn-Friese, "Containerization in Globalization": A Case Study of How Maersk Line Became a Transnational Company', in Shipping and Globalization in the Post-War Era, Palgrave Macmillan, Cham, 2019, pp. 103-131.

[3] D. Chaffey and F. Ellis-Chadwick, Digital marketing. Pearson UK, 2019.

[4] A. Ben Othman, "Internet marketing, SEM/SEO/SMO," HAAGA-HELIA ammattikorkeakoulu, 2010.

[5] B. Chaters, Mastering search analytics: Measuring Seo, SEM and site search. Sebastopol, CA: O'Reilly Media, 2011.

[6] D. E. Kurniawan, A. Dzikri, H. Widyastuti, E. Sembiring, and R. T. Manurung, 'Smart mathematics: a kindergarten student learning media based on the drill and practice model', J. Phys. Conf. Ser., vol. 1175, p. 12037, Mar. 2019.

[7] N. Puspita and W. Wardiyah, "The development of motion graphic as education material for promoting adequate home drug storage," SANITAS: Jurnal Teknologi dan Seni Kesehatan, vol. 10, no. 2, pp. 92-101, 2019.

[8] Danar, R., (2012). Pengaruh Iklan dengan EPIC Model pada Media Televisi Terhadap Sikap Penonton (Setudi Kasus apda Iklan Minuman Isotonik Fatigon Versi "Macet" di Kota Pekan Baru). Jurnal Sosial Ekonomi Pembangunan. 2(6):290320.

[9] R. E. Nuryaningsih, E. Sudarmilah, R. M. P. Siregar, and R. K. Ningrum, 'Motion Graphic Animation for Public Service Advertisement', J. Phys. Conf. Ser., vol. 1569, p. 42003, Jul. 2020

[10] Sugiyono, Metode Penelitian Kuantitatif, Kualitatif, dan R\&D. Bandung : Alfabeta, 2003.

[11] M. Ansori, Metode Penelitian Kuantitatif Edisi 2. Airlangga University Press, 2020.

[12] J. Krasner, Motion graphic design: Applied history and aesthetics, 2nd ed. London, England: Routledge, 2013.

[13] P. Hudson, Learning to Teach in the Primary School. Cambridge, England: Cambridge University Press, 2013.

[14] A. Rozalena and Universitas Garut, Indonesia, "Creative content on the digital campaign Tokopedia "Seller Story," J. 
Komun. Malays. J. Commun., vol. 36, no. 4, pp. 157-171, 2020

[15] X. Yang, "Exploration of the Motion Graphics Educational tools based on the animations "Weddings,", Rochester Institute of Technology, 2020.

[16] A. Prabowo, A. H. Thohari, and D. E. Kurniawan, 'Development of Interactive Learning Application for Vocational High School', 2019 2nd Int. Conf. Appl. Eng., pp. 1-4, Oct. 2019.

[17] A. S. Hapsari, M. Hanif, Gunarhadi, and Roemintoyo, "Motion graphic animation videos to improve the learning outcomes of elementary school students," Eur. J. Educ. Res., vol. 8, no. 4, pp. 1245-1255, 2019. 